BARBARA HARTLEB-KROPIDŁO

Uniwersytet Wrocławski

\title{
KOGO STRZEGŁY LARES PRAESTITES?
}

\begin{abstract}
Hartleb-Kropidło Barbara, Kogo strzegły Lares Praestites? (Whom where the Lares Praestites guarding?)

The paper discusses the Lares Praestites, whose role, customs, and festivities are described in Ovid's Fasti 5, 129-139. The poet shows the Lares Praestites as archaic guardians of the City of Rome.
\end{abstract}

Keywords: Lares Praestites; Ovid; Fasti; Roman religion.

Lary, rzymskie bóstwa opiekuńcze ${ }^{1}$, podobnie jak wiele innych bóstw, były obdarzane różnymi przydomkami, stanowiącymi niejednokrotnie precyzyjne określenie ich funkcji lub miejsca kultu². Wśród przydomków Larów należy wymienić przede wszystkim Familiaris (Rodzinny), nawiązujący do kultu sprawowanego w domu. Postać Lara jest ważnym bohaterem komedii Plauta zatytułowanej Aulularia, wygłaszającym prolog (Aulul. 1-5):

Ne quis miretur qui sim, paucis eloquar.

ego Lar sum familiaris ex hac familia

unde exeuntem me aspexistis. hanc domum

iam multos annos est cum possideo et colo

patri avoque iam huius qui nunc hic habet.

By nikt nie musiał łamać sobie głowy,

jak się nazywam, powiem wam w dwóch słowach:

ja jestem Larem. Tak, tak, Lar domowy

tej tu rodziny. Już wieku połowa

\footnotetext{
${ }^{1}$ Rzymianie uważali kult Larów za bardzo dawny. Na temat tych bóstw, a zwłaszcza ich natury, od wielu lat trwa w literaturze naukowej dyskusja. Różnie interpretowane testimonia antyczne doprowadziły do ugruntowania się dwóch teorii. Według pierwszej Lary to bóstwa związane z miejscem, według drugiej to ubóstwione duchy przodków. Badaczami związanymi z pierwszą teorią są między innymi: Wissowa (1912: 169-176); Kunckel (1974); Bömer (1981); Scheid (1990: 587-598); Bert Lott (2004). Za duchy przodków Lary są uważane przez: Samtera (1901: 105-123); Tabelinga (1932); Nieblinga (1956: 303-331); Bodela (2008); Kaczor (2012: 221-230).

${ }^{2}$ Przykładem może być bogini Junona, którą obdarzono licznymi epitetami, m.in: Caprotina, Cinxia, Covella, Curitis, Domiduca, Fluvonia, Interduca, Iugalis, Lucina, Moneta, Pronuba, Regina, Sororia, Sospita. Zob. Kaczor 2012: 158-172; Dury-Moyaers, Renard 1981: 142-202.
} 
minęła, odkąd strzegę i pilnuję

wpierw dziada, ojca, no a teraz tego,

co tutaj po nich w domu rezyduje.

Przeł. E. Skwara ${ }^{3}$

Znane są także Lares Permarini, Lary Żeglujących ${ }^{4}$, których świątynia została wybudowana na Polu Marsowym, w miejscu określanym dziś jako Largo (di Torre) Argentina. Jej wzniesienie ślubował dowódca floty Lucjusz Emiliusz Regillus, podczas wojny z Antiochem (192-188 p.n.e.), po tym jak przy przylądku Myonessos na Morzu Egejskim oddziały rzymskie rozbiły flotę Seleukidów, kończąc ich dominację na Morzu Śródziemnym. Zwycięstwo przypisano pomocy Larów, nadając im z tej okazji przydomek Permarini i wznosząc obiecaną świątynię, dedykowaną im 22 grudnia 179 r. p.n.e. przez cenzora Marka Emiliusza Lepidusa5

Szczególnie rozpowszechniony wśród mieszkańców Rzymu był także kult Larów Skrzyżowań, Lares Compitales, noszący nazwę Kompitaliów. Coroczne uroczystości koncentrujące się wokół ołtarzy usytuowanych u zbiegu dróg miały charakter rolniczy, związany z urodzajnością pól i dostatkiem plonów.

Teksty literackie oraz inskrypcje potwierdzają także użycie określenia Lares Viales, Lary Przydrożne. Bóstwa te zostały wspomniane przez nieszczęśliwie zakochanego młodzieńca Charinusa, bohatera komedii Plauta Kupiec, który postanawia wyruszyć w podróż, opuszczając swojego rodzinnego Lara. Oddaje się zatem pod opiekę Larów stojących na przydrożnych ołtarzach czy w kapliczkach, które będzie mijał podczas podróży po nieznanych i często niebezpiecznych krainach (Merc. 864-865):

Invoco

vos, Lares viales, ut me bene tutetis.

Wzywam was, Lary Dróg, i proszę, byście dobrze mnie strzegły ${ }^{6}$.

Określenie Lares Viales dość często występuje na kamieniach wotywnych ustawianych przy drogach na terenie prowincji Hiszpanii ${ }^{7}$. Na przykład:

Laribus / Vialibus / sacrum / Iul(ius) • Gaia/nus $・ v($ otum $) \cdot s($ olvit $) /$ l(ibens) a(nimo $)^{8}$.

${ }^{3}$ Skwara 2003: 131, w. 1-7.

${ }^{4}$ Permarinus, -a, -um: morski, towarzyszacy w podróży morskiej, Plezia 1959-1979: 110 (t. IV), s. v. permarinus.

${ }^{5}$ Ziółkowski 1992: 120; 236; 302.

${ }^{6}$ Plaut 1951, w. 882-883: G. Przychocki tłumaczy tę frazę: „,Was wzywam / Was Larowie dróg publicznych, strzeżcie mnie!”.

${ }^{7}$ Zbiór inskrypcji: Corell 1999. O inskrypcjach w Luzytanii zawierających dedykacje dla Larów z różnymi lokalnymi przydomkami vide: Redentor 2017. Zob. także Witczak 2005. Inskrypcje z obszarów dzisiejszej Hiszpanii i Portugalii dostępne są na stronie: www.europeana.edu.

${ }^{8}$ Ołtarz kamienny z granitu, o wymiarach $78 \times 34,5 \times 25 \mathrm{~cm}$, odnaleziono w jednym z kościołów Luzytanii (jest to kościół Matki Boskiej Wniebowstąpienia w Narros del Puerto, Ávila, Kastylia-León, Hiszpania). Zdjęcie na stronie: www.europeana.eu. 
Nazwa Viales wyraźnie zaznacza związek Larów z podróżowaniem, a ustawianie dedykowanych im kamiennych postumentów poświadcza, że uważano ich za opiekunów podróżujących. Zabytki zachowane na Półwyspie Iberyjskim, pochodzące przeważnie z II wieku n.e., dowodzą niemałej popularności kultu Lares Viales.

Z uwagi poczynionej przez Warrona w dziele De lingua Latina $(6,25)$ dowiadujemy się, że w czasach encyklopedysty identyfikowano Lares Compitales z Lares Viales: „Compitalia dies attributus Laribus vialibus”. Kompitalia to dzień poświęcony Larom Przydrożnym .

Wśród zachowanych określeń Larów spotykamy także przydomek Praestites - Strzegące, Stróżujące ${ }^{10}$. Są one bohaterami święta obchodzonego 1 maja, przedstawionego przez Owidiusza w Kalendarzu poetyckim (Fast. 5, 129-139):

Praestitibus Maiae Laribus videre Kalendae aram constitui parvaque signa deum:

voverat illa quidem Curius, sed multa vetustas destruit; et saxo longa senecta nocet.

causa tamen positi fuerat cognominis illis quod praestant oculis omnia tuta suis:

stant quoque pro nobis et praesunt moenibus Urbis, et sunt praesentes auxiliumque ferunt.

at canis ante pedes saxo fabricatus eodem stabat: quae standi cum Lare causa fuit?

servat uterque domum, domino quoque fidus uterque (...)

Widziały to kalendy w maju, jak powstawał ołtarz dla lar stróżujących i małe znaki bogów.

Zbudował ołtarz Kurius, lecz czas wiele zniszczył.

Starość szkodzi i skałom. Przyczyną przydomka

Larów jest, że wszystkiego czujnymi pilnują oczami. Wszak strzegą nas i murów miasta, są obok nas i niosą nam swą pomoc, a przy nich pies w kamieniu rzeźbiony, blisko stóp się trzymał. Jaka tego przyczyna? Obaj domu strzegą i panu są wierni.

Przeł. E. Wesołowska ${ }^{11}$

Publiczny kult Larów Skrzyżowań (Lares Compitales) był znany w Rzymie i jego okolicach. Na przełomie roku obchodzono bowiem Kompitalia, o których niejednokrotnie wspominają autorzy z różnych epok (np. Cato, Agr., 5,3,2;

\footnotetext{
${ }^{9}$ Przekład: B. Hartleb-Kropidło.

${ }^{10}$ Lares Praestites są przedstawiane jako opiekunowie państwa rzymskiego. Jaczynowska (1987: 26) wśród bóstw opiekuńczych domu, Geniusza, Janusa, Westy, Penatów, Dei Manes, czy Terminusa wymienia oczywiście Lary, zaznaczając, że Lares praestites były wyobrażeniem Larów całego państwa.
}

${ }^{11}$ Owidiusz 2008: 199. 
57, 1, 6; Cic, Att. 2, 3, 4). Majowe uroczystości opisane przez Owidiusza nie są potwierdzone przez wcześniejsze testimonia. O ich początkach informuje nas Swetoniusz ${ }^{12}$ : to August wprowadził nowe święta ku czci Larów, nakazując w tych dniach dekorowanie kwiatami posągów Larów znajdujących się w miejscach publicznych. Cesarz rozszerzył dawny kult Larów o kult swojego ducha ożywiającego (Genius Augusti). Owidiusz, aby wykazać pradawne pochodzenie święta, świadkami niegdysiejszych obchodów uczynił Kalendy majowe, które w odległej przeszłości miały obserwować wznoszenie ołtarza ofiarnego dla Larów.

Obchody Kompitaliów organizowano lokalnie, na terenie wsi - u zbiegu dróg łączących posiadłości, na terenie miasta - w wyznaczonych miejscach, nazywanych vici. Rzym był podzielony na jednostki administracyjne, większe - regiones (dzielnice miasta) oraz mniejsze - vici (szereg domów, dzielnica). Wiemy, że w efekcie reformy administracyjnej przeprowadzonej przez Augusta w 8 r. p.n.e. utworzono na terenie Rzymu 14 regiones i 265 vici ${ }^{13}$. Jednostki te miały znaczenie polityczne, ale także religijne, ponieważ każdy vicus wybierał swoich tak zwanych vicomagistri, którzy organizowali lokalne uroczystości religijne, początkowo głównie Kompitalia. To święto poświęcone Larom Skrzyżowań było świętem ruchomym, którego datę, w czasie od końca grudnia do początku stycznia, corocznie wyznaczał pretor (praetor urbanus). Uroczystości ku czci Larów miały na celu zapewnienie mieszkańcom ich opieki, która była źródłem urodzaju i wynikającego z niego dobrobytu.

Owidiusz, mówiąc o majowym święcie, zwraca szczególną uwagę na miejsce kultu, opisując je tak, aby słuchacz bądź czytelnik odnalazł analogię między dawnymi, zimowymi Kompitaliami a nowym świętem Larów obchodzonym 1 maja, pomija natomiast fakt zmiany terminu święta. Podkreśla za to archaiczność kultu, wspominając postawiony dawniej, ale niezachowany do jego czasów, kamienny ołtarz. Miał go ufundować niejaki Kuriusz, poeta jednak nie przekazuje nam żadnych informacji, aby można było wskazać konkretną osobę.

Postać Kuriusza (o ile poprawnie odczytano imię, ponieważ stan zachowania rękopisów pozwala „odszyfrować” jedynie początek wyrazu: Cur) ${ }^{14}$ występuje w tekście Fasti tylko raz. Próbowano łączyć to imię z Maniuszem Kuriuszem Dentatusem, pogromcą Sabinów (290 r. p.n.e.) i Pyrrusa, króla Epiru (275 r.

${ }^{12}$ Suet., Vita Caes. Aug. 31, 4: „Compitales Lares ornari bis anno instituit vernis floribus et aestivis".

${ }^{13}$ Cary, Scullard 1992: 78; 89. W literaturze polskiej spotyka się różne tłumaczenia terminów regio i vicus. Na przykład: dzielnice i dystrykty (Flaig 2013: 216) lub: okręgi i obwody (Dębiński, Misztal-Konecka, Wójcik 2010: par. 23). Łacińskie nazewnictwo zachowuje m.in. Sajkowski (2000: 57).

${ }^{14}$ Interpretacji tego urywka jest kilka. Zob. Bonniec 1960: 211-212 oraz Alton, Courtney, Wormell 1973: 146-148. Badacze wykazują, że w przypadku wyrazu Curius wątpliwości nie ulega jedynie odczytanie litery U. 
p.n.e. w bitwie pod Benewentum), ale identyfikacja ta nie jest przekonujacca, trudno bowiem odgadnać, dlaczego to on miałby być przywołany jako symbol pobożności ${ }^{15}$. Maniusz Kuriusz Dentatus znany był jako inicjator działań, które doprowadziły do osuszenia bagnistego terenu w pobliżu równin Terni poprzez utworzenie kanału (Cavum Curianum), prowadzącego do przełęczy Marmoris, skąd woda wpływała do rzeki Niger, a następnie do Tybru, na dawnym terytorium Sabinów ${ }^{16}$. Powodem przywołania wspomnianego Kuriusza może być także wybudowanie (za pieniądze pozyskane w wojnie z Pyrrusem, r. 272 p.n.e.) akweduktu Aqua Anio Vetus, drugiego pod względem wydajności po Aqua Appia, zasilającego w wodę duży obszar Rzymu ${ }^{17}$. Brakuje nam wiadomości o działalności Kuriusza w sferze religijnej; w zestawieniu z treścią niniejszych wersów poematu jego postać wydaje się zbyt mało archaiczna.

O ustawieniu ołtarza poświęconego Larom przez króla Tytusa Tatiusa dowiadujemy się z działa Warrona (Ling. 5, 74), wątpliwe jednak, że o tym władcy mówi Owidiusz ${ }^{18}$. Może Kuriusz to postać niehistoryczna, legendarna bądź fikcyjna, która miała swoim imieniem wywoływać skojarzenia ze starorzymską kurią, wspólnotą opartą na związkach rodowych?

Owidiusz zwięźle opisuje miejsce kultu, zwracając uwagę na to, jakie było dawniej i jakie jest współcześnie. W sąsiedztwie ołtarza wzniesionego przez wspomnianego Kuriusza kiedyś znajdowały się niewielkie, a zapewne także skromne figurki Larów (parva signa deum) ${ }^{19}$. Miejsce to zostało zniszczone przez czas, a sam kult utracił swoje znaczenie i zanikł. Obecnie, zdaniem poety, Lares Praestites zgodnie ze swoim przydomkiem czuwają (praestant), aby zapewnić bezpieczeństwo mieszkańcom Miasta i, kiedy trzeba, nieść im pomoc.

Opisując święto dedykowane Larom, Owidiusz wskazuje na istotne elementy umieszczone w miejscu kultu: w dawnej świątyni u stóp Larów siedział

${ }^{15}$ Fauth 1978: 121.

${ }^{16}$ Dzisiejszy wodospad Le Marmore w Terni powstał w miejscu, gdzie rzeka Velino spływając z wyżyn od strony miasta Rieti, spowalniała swój bieg z powodu nagromadzonych tam skał wapiennych, tworząc rozlewiska powodujące niezdrowe powietrze i choroby. Wykopany kanał prowadził wody do wodospadu Marmore, a stamtąd do rzeki Niger, dopływu Tybru.

${ }^{17}$ Frontin, De aquis, 1, 6-20. Brennan 1994: 423-439.

${ }^{18}$ James Frazer w komentarzu do Fasti 5, 129 (Frazer 1989: 12-16) proponuje odczytanie tego nazwiska jako Tatius, budzi to jednak wątpliwości. Zob. przypis 14.

${ }^{19}$ Rzeczownika signum na określenie rzeźby boga Apollina używa Lucjusz Celiusz Antypater w datowanym na rok 215 p.n.e. fragmencie (Zob. Cornell 2013: 418): F 60, Serv. Ad. Aen. 6, 9-11:

(V) „at pius Aeneas arces quibus altus Apollo

praesidet...

...petit...

„(DS) Coelius enim de Cumano Apolline ait: est in fano signum Apollinis ligneum, altum non minus pedes XV.".

(=Peter F 54, Hermann F 61, Chasignet F 30).

Także: Cic. Verr. 1,45: „Iam quae iste signa, quas tabulas pictas ex Achaia sustulerit, non dicam hoc loco". 
wyrzeźbiony w kamieniu pies, który przepędzał złodziei, dziś natomiast towarzyszy im Geniusz Augusta, który strzeże Rzymu ${ }^{20}$. Ten symboliczny obraz ma także wymiar rzeczywisty - August, obdarzony wyjątkową władzą i uprawnieniami był faktycznie osobą zapewniającą mieszkańcom pokój i bezpieczeństwo.

Poeta dokłada starań, aby odbiorca utworu wiedział - czy może dowiedział się? - i właściwie rozumiał, co oznacza przydomek Praestites i jaką funkcję pełnią obdarzone nim Lary. Dokładnie zatem wyjaśnia zakres semantyczny rzeczownika praestes; nie może jednak przywołać jakichkolwiek istniejących obiektów związanych z tak określanymi Larami, takich jak na przykład świątynie, gaje, czy przedstawienia artystyczne bądź kultowe. Przydomek praestes nie stał się też trwałym określeniem jakiekolwiek innego znanego nam bóstwa, także autorzy starożytni nie poświadczają innego użycia go w odniesieniu do Larów.

Owidiusz kilkukrotnie posługuje się czasownikami z przedrostkiem prae-, nawiązującym do przydomka Praestites, aby wzmocnić i uwydatnić znaczenie tego rzeczownika, ponieważ nie jest to przydomek popularny. Oprócz wyraźnego brzmieniowego podobieństwa wyrazów, co dla starożytnych miało szczególne znaczenie, uwagę zwraca także ich zakres semantyczny związany oraz mający wywoływać skojarzenia z opieką roztaczaną przez Lary, obejmującą wszystkich mieszkańców miasta.

Są to następujące czasowniki:

- praestare: stać na przedzie, ale także: zachowywać, utrzymywać, strzec;

- praeesse: stać na czele, sprawować zwierzchnią władzę, przewodniczyć, kierować, zarządzać, ale także: strzec, chronić, opiekować się;

- praesens: (participium praesentis od czasownika praeesse), osobiście obecny, we własnej osobie, sam, ale także: 1. pomocny, przychylny, łaskawy; 2. pomocny, niezawodny, skuteczny;

\footnotetext{
${ }^{20}$ Fast. 5, 141-142:

„exagitant et Lar et turba Diania fures:

pervigilantque Lares, pervigilantque canes.

oraz: $5,145-146$ :

mille Lares Geniumque ducis, qui tradidit illos,

Urbs habet (...)".

„Lary i Diany sfora przepędzą złodzieja.

Lary czuwają tak samo, jak i psy czuwają.

(...) Miasto ma tysiąc larów i geniusza władcy".
}

Przeł. E. Wesołowska.

Owidiusz prezentuje pogląd, że dzięki staraniom Augusta Rzym jest bezpieczny, nie zagrażają mu już żadni wrogowie, ponieważ nad mieszkańcami czuwają Lary oraz Geniusz władcy, podobnie jak czuwają psy odstraszające złodziei. 
- stare pro: stać po czyjejś stronie, wspierać, wspomagać kogoś, trzymać z kimś, stać w obronie kogoś ${ }^{21}$.

Nagromadzenie zbliżonych znaczeniowo czasowników stwarza i podtrzymuje odczucie roztaczanej opieki. Aby natomiast zaakcentować jej powszechność, wskazani zostali także beneficjenci: pro nobis, moenibus Urbis (Fast. 5, 134-136). To drugie określenie sygnalizuje także, że Miasto nie jest zagrożone przez wrogów zewnętrznych, ponieważ za sprawą Augusta zapanował w nim pokój. Przypisywanie takiej funkcji Larom wykracza nieco poza tradycyjnie wyobrażenie ich działania.

quod praestant oculis omnia tuta suis:

stant quoque pro nobis et praesunt moenibus Urbis, et sunt praesentes auxiliumque ferunt.

Staranność i skrupulatność Owidiusza w doborze oraz sposobie użycia wymienionych czasowników wskazuje na to, że umiejętnie i celowo kształtuje on także zakres semantyczny wyrazu praestes, przedstawiając dzięki temu również jego „etymologię”, jednocześnie programując rozumienie tego terminu przez odbiorców tak, aby było zgodne z oczekiwaniami poety.

Warto bliżej przyjrzeć się znaczeniu oraz użyciu rzeczownika praestes, -itis. Słownik łacińsko-polski pod redakcją Mariana Plezi wskazuje na jego pochodzenie od czasownika praestare oraz podaje dwa znaczenia ${ }^{22}$ :

1. Przełożony, naczelnik Gloss.

2. Strażnik, opiekun, obrońca; w takim znaczeniu u Owidiusza (Fast. 5, 129) oraz u autorów późniejszych, od II w. n.e. (Rec.).

Niewielka liczba cytatów przywołanych w haśle sugeruje niezbyt częste użycie tego wyrazu.

Lexicon Totius Latinitatis ${ }^{23}$ objaśnia znaczenia rzeczownika praestes (uważanego za masculinum i femininum) jako (wł.) presidente, przewodniczacy, prezes; protettore, opiekun, protektor ${ }^{24}$; podaje także odpowiednik grecki $\left.\pi \alpha \rho \alpha \sigma \tau \alpha \dot{\tau}\right\rceil \varsigma$,

${ }^{21}$ Takie znaczenie wyrazów podają słowniki łacińsko-polskie: Plezia 1959-1979: 267-268 (t. IV) s.v. praesto, -are; 269-270 s.v. praesum, -esse; 264 s.v. praesens, -ntis; t. V: 220-221 s.v. sto, -are; oraz Korpanty 2001: 505-506 (t. II), s.v. praesto, -are; 507 s.v. praesum, -esse; 503-504 s.v. praesens, -ntis; 768-769, s.v. sto, -are.

${ }^{22}$ Plezia 1959-1979: 267-268 (t. IV): praesto, -are, -stiti (-avi ICt.), -stitum i statum ma wiele znaczeń, m. in. stać na przedzie, przewyższać, wyróżniać się; przewyższyć, prześcignąć kogoś; poręczyć, zabezpieczyć, być odpowiedzialnym za coś; wykazać; spełnić, wykonać; wypłacić; wystawić na coś itp. Taki sam zakres znaczeniowy tego czasownika uwzględnia Korpanty (2001: 505-506, t. II), stąd też takie same znaczenia interesującego nas rzeczownika praestes (Korpanty 2001: 505, t. II): 1. strażnik, opiekun, obrońca 2. poklas. przełożony, naczelnik).

${ }^{23}$ Forcellini 1945: 833, s.v. praestes.

${ }^{24}$ Meisels 1999: 226, s. v. president, oraz 243 s. v. protettore. 
m.in. stojący obok, stróż, towarzysz broni, pomocnik, obrońca ${ }^{25}$ oraz synonim łaciński praeses; m.in. stróż, opiekun, obrońca, władca, naczelnik, przełożony ${ }^{26}$.

Walde i Hofmann, autorzy słownika etymologicznego, także podają podobne znaczenia: naczelnik, przełożony (Vorsteher) oraz opiekun, obrońca (Schützer) ${ }^{27}$.

Słownik Oxford Latin Dictionary podaje natomiast jedynie znaczenie praestes: strażnik, zwracając szczególną uwagę na zastosowanie tego terminu w stosunku do bóstw opiekuńczych ${ }^{28}$. W Thesaurus Linguae Latinae ${ }^{29}$ hasło zajmuje około pół kolumny. Autorka hasła, Marianne Pade, podaje etymologię wyrazu oraz jego znaczenie:

Praestes, -itis, m. i. qui ante stat, sc. qui sive custodiendo, defendendo sive regendo, administrando praeest (...).

Pierwszym z przykładów jest wyrażenie Dei Penates Praestites, jak odczytywano dawniej skrót DPP umieszczony na monetach pochodzących z końca II wieku p.n.e. Dziś jest on rozumiany jako skrót Dei Penates Publici ${ }^{30}$ (Penaty Państwowe). Penaty, kojarzone głównie z kultem domowym, czczone przy domowym ognisku, odbierały także kult państwowy, powiązany z legendą o przybyciu Eneasza do Italii. Miał on zabrać z płonącej Troi swoje bóstwa domowe, które później umieszczono w świątyni Westy. Penatom poświęcono w Rzymie świątynię Aedes Deum Penatium, mieszczącą się na wzgórzu Velia ${ }^{31}$. Przypuszcza się, że jej wizerunek zachował się na fragmencie ołtarza Ara Pacis ${ }^{32}$ :

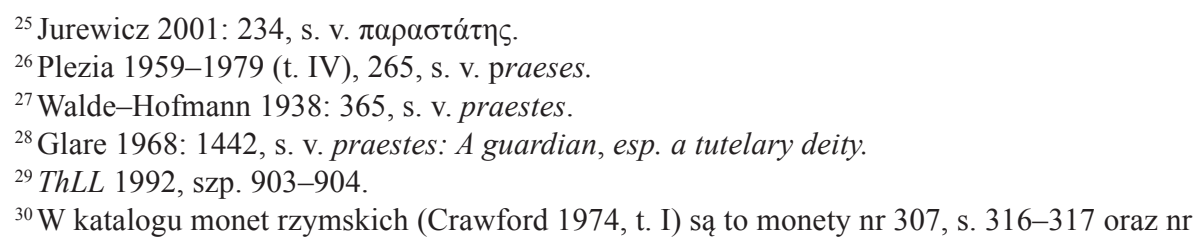
312, s. 320.

Opinię Cycerona na temat Penatów prezentuje Jenkyns 2013: 201-202. Penaty często później utożsamiano z Kastorem i Polluksem, zob. Dubourdieu 1989, http://www.persee.fr/doc/efr_00000000_1989_ths_118_1 (dostęp: 02.10. 2017); a także Orr 1978: 1557-91, zwł. 1562-1563.

O Penatach oraz Aedes Castoris zob. Sumi 2009: 177-179.

${ }^{31}$ Zniszczona w wyniku uderzenia pioruna w 167 r., odbudowana z inicjatywy Augusta. Zob. Palombi 1997. Artykuł dostępny w: [academia.edu].

Według Ziółkowskiego (1992: 128-137) świątynia pochodzi z lat 292-219 p.n.e. Stała prawdopodobnie u podnóża góry (w części północnej lub zachodniej). Wskazuje na to opis Dionizjusza z Halikarnasu w Ant. Rom. 1, 68, 1 oraz wzmianka Warrona w Ling. 5, 54, 1), dotąd nie zidentyfikowano żadnych jej pozostałości.

${ }^{32}$ Rekonstrukcja ołtarza w oparciu o licznie zachowane fragmenty marmurowych reliefów jest prezentowana w Museum Ara Pacis w Rzymie. Umieszczenie na ołtarzu wizerunku Penatów i ich świątyni związane jest z ożywieniem tradycji mitologicznej i historycznej Rzymu, a zwłaszcza z przedstawianiem Eneasza jako praprzodka Rzymian oraz tego, który z Troi przywiózł do Lawinium rodzinne Penaty. Uważano, że były one później rzymskimi Penatami Państwowymi. Interpretację prezentującą pogląd, że August widział się w roli nowego Eneasza, jako odnowiciela 


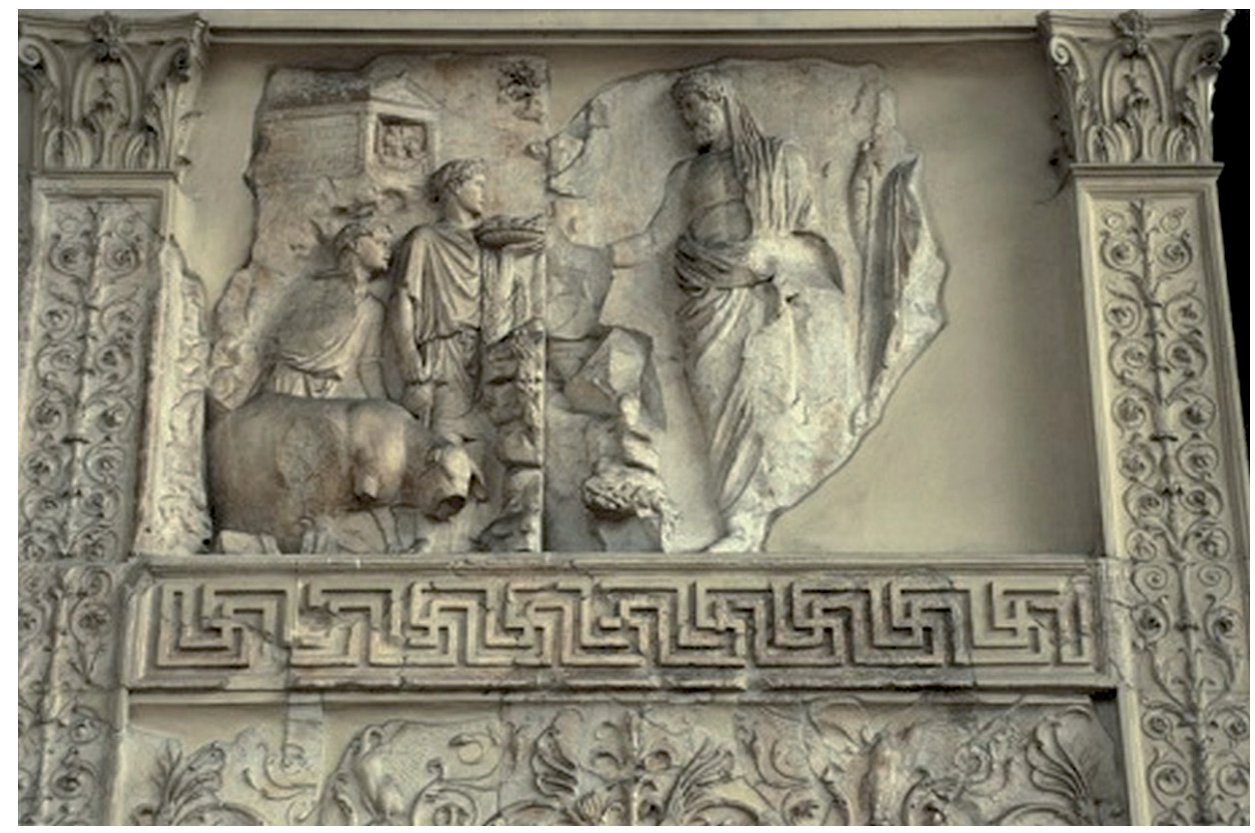

Fragment ołtarza Ara Pacis. Eneasz składający ofiarę ze świni. W tle świątynia Penatów.

Ara Pacis, zdjęcie w domenie publicznej, dostęp: 27. 04. 2018.

[https://www.college.columbia.edu/core/sites/core/files/images/Aeneas\%20sacrificing\%20 a\%20sow $\% 2$ C $\% 20$ Ara $\% 20$ pacis.png]

Jedną ze wspomnianych monet zawierających skrót DPP jest denar rzymski pochodzący z roku 106 p.n.e., na którego awersie widnieją dwie męskie głowy w wieńcach laurowych. Na rewersie przedstawieni zostali dwaj wojownicy, trzymający w lewych rękach włócznie, a prawymi wskazujący na znajdującą się między nimi świnię̧3. Napis C. S U LP I C I.CF wskazuje na emitenta monety, Gajusza Sulpicjusza Galbę. Jest on najprawdopodobniej synem kapłana Gajusza Sulpicjusza Galby, skazanego na wygnanie na mocy lex Mamilia w 109 r. p.n.e., a także wnukiem słynnego mówcy Serwiusza Galby, konsula ze 144 r. p.n.e. ${ }^{34}$.

Trudno wskazać, dlaczego Sulpicjusz umieścił wizerunek Penatów na awersie monety; być może ma to związek z kapłańską funkcją pełnioną przez ojca emitenta lub przez niego samego, a wybicie tej monety miało służyć upamiętnieniu znakomitości rodu.

religii zawiera artykuł Stöckingera (2013: 129-148). Zob. także Thomson de Grummond 1996: 59-61.

${ }^{33} \mathrm{~W}$ wymienionym zbiorze monet (Crawford 1974) jest to moneta $\mathrm{nr} 312 / 1$.

${ }^{34}$ RE Sulpicius 9; Farney 2007: 259-260. 


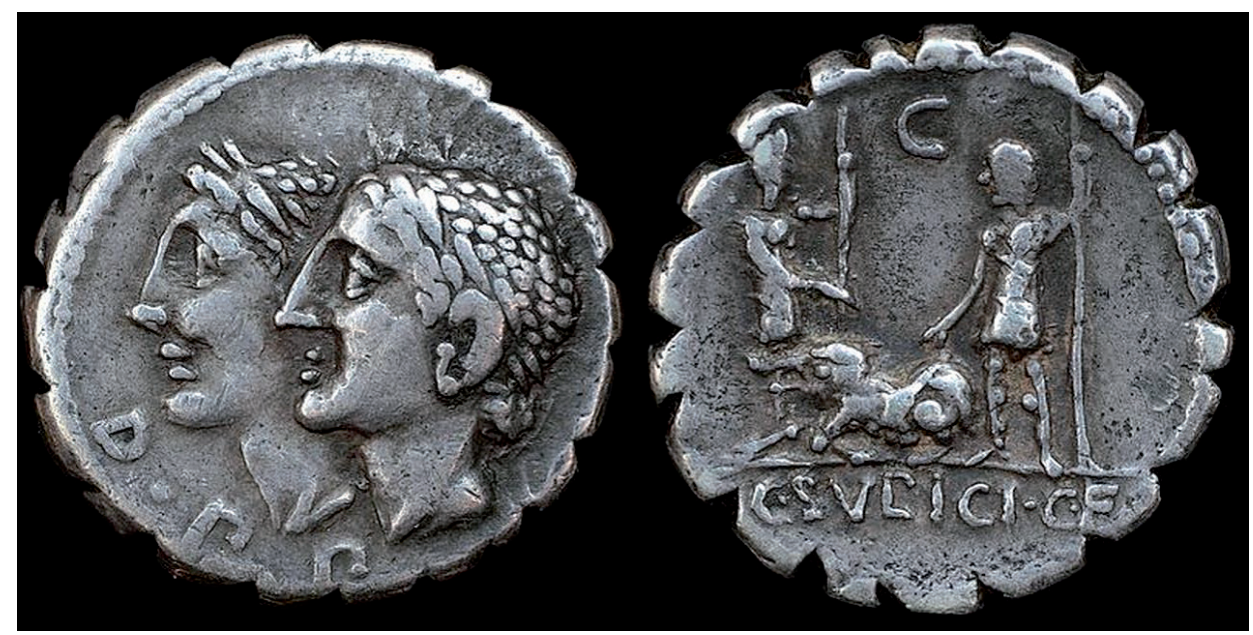

Moneta Dei Penates Publici, zdjęcie w Creative Commons

By Johny SYSEL [CC BY-SA 3.0 (https://creativecommons.org/licenses/by-sa/3.0)], from Wikimedia Commons

Dawniejsza interpretacja skrótu DPP jako Dei Penates Praestites, dziś, jak powiedzieliśmy, nieaktualna i nieuzasadniona, sprawia, że napis na monecie nie jest poświadczeniem występowania rzeczownika praestes.

Kolejną monetą wymienioną $w$ treści hasła jako przykład użycia słowa praestes, jest srebrny denar Lucjusza Cezjusza datowany na lata 112/111 p.n.e. Analizą treści tej monety zajmujemy się w innym studium.

Przykładem zastosowania rzeczownika praestes jest inskrypcja umieszczona na ołtarzu poświęconym Jowiszowi w miejscowości Tibur, wzniesionym w czasach Augusta lub Tyberiusza (CIL 14, 3555):

Iovi Praestiti Hercules Victor dicavit Blandus pr(aetor) restituit.

Wspomniany Blandus to Caius Rubelius Blandus, rzymski polityk z przełomu er ${ }^{35}$, który poprzez tę inskrypcję upamiętnia odbudowę ołtarza Jowisza, wzniesionego według legendy przez Herkulesa ${ }^{36}$. Inskrypcja pochodzi zatem z czasów Owidiusza lub nieco późniejszych. Jowisz jest w niej przedstawiony jako opiekun, obrońca. Odnowienie ołtarza ma niewątpliwie związek z działaniami z zakresu religii podjętymi przez Augusta, które objęły także okolice Rzymu. Być może określenie praestes nawiązuje do terminu zastosowanego przez poetę w opisie Larów.

${ }^{35}$ Consul suffectus roku 18 n.e. Wiemy, że w 33 r. n.e. poślubił wnuczkę Tyberiusza, Julię Liwię (córkę Liwilli i Juliusza Cezara Druzusa).

${ }^{36}$ Várhelyi 2010: 117-118. 
Kolejna inskrypcja (pochodząca z miejscowości Poetovio w prowincji Pannonia Superior, CIL 3, 4037, obecnie w Grazu), która została umieszczona na ołtarzu (wys. $147 \mathrm{~cm}$, szer. $78 \mathrm{~cm}$, gł. $56 \mathrm{~cm}$ ) wymienia Jowisza jako obrońcę, także w kontekście militarnym:

Prestito (sic!) Iovi s(acrum) C(aius) Fulvius Plautianus tribunus coh(ortis) X praetoriae cultor numinis ipsius proficiscens ad opprimendam factionem Gallicanam iussu principis sui aram istam posuit ${ }^{37}$.

Czas powstania inskrypcji ${ }^{38}$ to koniec II wieku n.e. (najczęściej przyjmuje się rok 196 lub 197), prawdopodobnie czasy panowania Septymusa Sewera. Fundator ołtarza jest nieznany ${ }^{39}$. Treść napisu mówi, że jest to wotum w intencji powodzenia wyprawy wojennej ${ }^{40}$, a jej adresatem jest Jowisz jako bóg mogący je zapewnić.

Zwraca uwagę użycie formy praestito w miejsce praestiti, co świadczy o występowaniu zjawiska tzw. przechodzenia rzeczowników z deklinacji III do II, typowego dla języka niższych warstw społecznych, sermo vulgaris, a także łaciny przed- i poklasycznej ${ }^{41}$.

Jako epitet Jowisza rzeczownik praestes poświadczony jest także w Hist. Aug., $\operatorname{Max} .{ }^{42}$ 5,3:

in proximum sacellum, quod erat Iovis Praestitis, detulisse $\mathrm{e}^{43}$

Tekst dotyczy wydarzeń z III wieku i wspomina o jakimś współczesnym ołtarzu, kapliczce bądź świątyni Jowisza z przydomkiem Praestes; budowla ta jest

${ }^{37}$ Treść inskrypcji zawarta w CIL jest częściowo rekonstruowana. Nazwisko fundatora jest niezachowane. Fotografia kamiennego ołtarza jest dostępna na:

http://dh-www.adw.uni-heidelberg.de/iiif/edh/HD066121 (dostęp: 02.05.2018).

tam także tekst inskrypcji:

[Pr(a)estito Iovi s(acrum) / [[[------]]] / tribunus coh(ortis) X / praet(oriae) cultor nu/minis ipsius profic/iscens ad opprimen/dam factionem / Gallicanam iuss $[\mathrm{u}] /$ principis sui ara[m] / istam posuit].

Zdjęcie: http://www.ubi-erat-lupa.org/imagelink/index.php?Nr=4962 (dostęp: 03.05. 2018).

${ }^{38}$ Handy 2009: 45.

${ }^{39}$ Stein (1910: 272) odrzuca tezę, że to C. Fulvius Plautianus.

${ }^{40}$ Przypuszczenie, że wybuch zamieszek na terenie Gallii był inspirowany przez Klodiusza Albina (Clodius Albinus) wysuwa Urban (1999: 85-87).

${ }^{41}$ Zob. Stankiewicz 1987: 58 oraz Stankiewicz 1999: 256-258.

${ }^{42}$ Maksymus czyli Gaius Iulius Verus Maximus był cesarzem rzymskim od 236 roku do marca/ kwietnia 238 roku, natomiast Balbinus czyli Decimus Caelius Calvinus Balbinus Pius Augustus był (wraz z Pupienusem) rzymskim cesarzem przez trzy miesiące 238 roku.

${ }^{43}$ Rękopisy (P - Palatinus 899 z IX wieku ): praestiti. Za: Hohl 1997: 60, aparat krytyczny ad 24 . 
skądinąd nieznana. W tym fragmencie termin praestes także określa opiekuńczą rolę Jowisza.

Podobnie w poniższym przykładzie, w którym Juliusz Waleriusz także wymienia bogów ${ }^{44}$ :

... illi dii, praestites et maiores tui, laetitiam suis ... peperere ${ }^{45}$ ?

W dziele Makrobiusza Saturnalia określenie praestes użyte jest trzykrotnie na określenie opiekuńczej roli bogów.

Gdy mowa o bogu Liberze czyli Bakchusie pada następujące określenie (1, 18, 17):

idem versus Orpheici Euboulea vocantes boni consilii hunc deum praestitem monstrant.

W innym miejscu utworu $(1,19,17)$ wymienione są cztery bóstwa: Daimon, Tyche, Eros, Ananke jako opiekunowie rodzącego się człowieka:

deos praestites homini nascenti quattuor adesse memorantes, Daimona, Tychen, Erota, Ananken

i po raz trzeci $(1,23,6)$ gdy mowa o gwiazdach jako bogach:

sidera signorumque praestites dei.

Rzeczownik praestes w znaczeniu opiekun, obrońca jest poświadczony dwukrotnie w dziele Marcjana Kapelli, De nuptiis Philologiae et Mercurii z V wieku. Kapella, mówiąc o Geniuszu, kładzie nacisk na jego funkcję opiekuńczą, związaną z wszelką aktywnością człowieka, pomija natomiast tradycyjnie pojmowaną rolę bóstwa jako siły życiowej, gwarantującej istnienie jednostki ${ }^{46}$ $(2,152)$ :

Genius amovetur, quem etiam praestitem, quod praesit gerundis omnibus, vocaverunt.

W innym miejscu utworu wymienia Kapella boginie świata podziemnego, Manę i Mantuonę, które uważa za szczególnie ważne w gronie bóstw chtonicznych $(2,164)$ :

Summanes eorumque praestites Mana atque Mantuona.

\footnotetext{
${ }^{44}$ Iul. Val., Ad Alex., 1, 52, vers. 18; Kuebler 1888. To wydanie zostało zacytowane w ThLL. Nowsze wydanie: Rosellini 2004: 1, 46, 1598-1599, zawiera taki sam tekst.

${ }^{45}$ Wzmianka o tym fragmencie oraz tekst zawarty w: Braccini 2004: XIV-XV.

${ }^{46}$ Kaczor 2012: 281.
} 
O dawniejszym znaczeniu wyrazu praestes mówi Festus, którego słowa przytacza Paweł Diakon (s. 250 L) ${ }^{47}$, zwracając uwagę na synonimiczność z rzeczownikiem antistes:

Praestitem in eadem significatione dicebant antiqui, qua nunc dicimus antistitem ${ }^{48}$.

Marianne Pade, autorka hasła praestes w Thesaurus Linguae Latinae zauważa, że pierwotne znaczenie wyrazu wynikające ze znaczenia jego elementów składowych, przedimka prae (przed) oraz czasownika stare (stać), określa tego, kto przewodzi innym: ,is qui ducendo aliis praeest”, a nie tego, kto chroni innych: ,is qui custodiendo ante aliis stat"49.

Zachowane i przytoczone przykłady użycia rzeczownika praestes pochodzą z różnych epok, co pozwala zauważyć pewną zmianę użycia i znaczenia wyrazu. Przeważa użycie wyrazu w znaczeniu obrońca, strażnik, opiekun, odnoszące się przede wszystkim do bogów. Określenie Lares Praestites nie zostało potwierdzone przez inne świadectwa literackie ani epigraficzne zarówno z czasów Owidiusza, jak i wcześniejszych lub późniejszych.

Spotykamy jednak inne określenie Larów: Lares Augusti ${ }^{50}$. August bowiem, akcentując konieczność odnowienia religii, wprowadził kult Larów z przydomkiem nawiązującym do swojego imienia, połączony z kultem swojego Geniusza. Uroczystości ku czci Larów z przydomkiem Augusti i Geniusza Augusta, które organizowano w Rzymie oraz w wielu miejscowościach na terenie Italii ${ }^{51}$ były, w opinii wielu uczonych, sposobem podkreślania jego nadzwyczajnej roli i pozycji. Organizacją kultu zajmowały się specjalne kolegia, złożone z niewolników i wyzwoleńców, nazywanych magistri vici i ministri vici. Przykładem takiej działalności są ołtarze kompitalne. Najdawniejsze ślady obchodów, pochodzące z 7/6 r. p.n.e. zachowały się na odkrytym ołtarzu usytuowanym przy Porticus Aemilia, wraz ze spisem magistri vici odpowiedzialnymi za organizację kultu.

Zachował się także w dużej części marmurowy ołtarz z tak zwanego Vicus Sandalarius, leżącego w pobliżu świątyni bogini Tellus, datowany na 2 r. p.n.e. ${ }^{52}$.

${ }^{47}$ Lindsay 1913.

${ }^{48}$ Plezia (1979-1959: 215, t. I) podaje następujące znaczenia wyrazu antistes, -itis: przełożony, dozorca, dozorczyni, przodujący w czymś, mistrz, naczelny kapłan, kapłan, biskup chrześcijański, kapłanka.

${ }^{49}$ Taką analizę znaczenia przedstawiają słowniki etymologiczne; zacytowany przez autorów hasła (Walde-Hofmann 1938: 356): „vor einer Sache oder Person stehend undi die schützend”, oraz Vaan de (2008: 485-486): prae ,in front of, before”; praesto pochodzi (prawdopodobnie) od wyrazów o znaczeniu ,standing in front” lub ,placed in front”.

ThLL, 1992, Vol. X, 2, fasc. VI, s.v. praestes, -itis.

${ }^{50}$ Beard, North, Price, 1998: 184-186; 355.

${ }^{51}$ Zob. Palmer, 1990; Beard, North, Price 1998: 184-197; Bert Lott 2004: 107.

${ }^{52}$ Obecnie we Florencji, w Galleria degli Uffizi, nr inw. 972, zakupiony w 1584 roku przez Ferdynanda I Medyceusza (Ferdinando I de' Medici). 
Ma on wymiary: wysokość $-110 \mathrm{~cm}$, szerokość $-90 \mathrm{~cm}$, głębokość $-60 \mathrm{~cm}$. Na jego powierzchni znajdują się rzeźby, m.in. przedstawiająca scenę składania ofiary oraz Lary, a także inskrypcja dedykacyjna (CIL VI 448?) ${ }^{53}$ :

Imp(eratore) Caesare Augusto XIII M(arco) Plautio Silvan(o) co(n)s(ulibus) / D(ecimus) Oppius |(mulieris) 1(ibertus) Iaso D(ecimus) Lucilius D(ecimi) 1(ibertus) Salvius L(ucius) Brinnius |(mulieris) 1(ibertus) Princeps L(ucius) Furius L(uci) 1(ibertus) Salvius / mag(istri) vici sandaliari // Laribus Augustis.

Autorzy, wyzwoleńcy będący fundatorami ołtarza, a także organizatorami i opiekunami kultu w wymienionej dzielnicy (Vicus Sandalarius) dedykują ołtarz Larom z przydomkiem Augusti (Genius Augusti nie jest wymieniony).

$\mathrm{Z}$ czasów panowania Augusta pochodzą także inne ołtarze umieszczane na skrzyżowaniach (najczęściej zachowane częściowo), które były poświęcone $L a$ ribus Augustis, na przykład ołtarz na Vicus Compitii Acilii, Vicus Aesculeti czy Vicus Statae Matris ${ }^{54}$.

Z kultem Larów propagowanym przez Augusta wiąże się także kult Larów Państwowych, Lares Publici. Świadczy o nim pochodzący z 4 r. p.n.e. marmurowy podest ołtarza zawierający inskrypcję dedykacyjną (CIL 4, 456):

Laribus Publicis sacrum

Imp(erator) Caesar Augustus

Pontifex Maximus

Tribunic(ia) potestat(e) XVIIII

ex stipe quam populus e[i]

contulit K(alendis) Ianuar(iis) apsenti

C(aio) Calvisio Sabino L. Passieno Rufo co(n)s(ulibus).

(Ołtarz) poświęcony Larom Państwowym

Imperator Cezar August

Najwyższy Kapłan

$\mathrm{z}$ władzą trybuna ludowego po raz dziewiętnasty

z datków złożonych mu przez lud

wzniósł w Kalendy styczniowe nie będąc osobiście obecnym podczas uroczystości

za konsulatu Gajusza Kalwizjusza Sabina i Lucjusza Passienusa Rufusa ${ }^{55}$.

Świadectwa literackie oraz epigraficzne (zwłaszcza inskrypcje dedykacyjne na zachowanych ołtarzach), w których występuje określenie Lares Augusti, a w których brak poświadczenia użycia sformułowania Lares Praestites, mogą prowadzić do wniosku, że nazwa użyta przez Owidiusza nie jest trwałym epitetem, a jedynie określeniem i podkreśleniem funkcji Larów jako bóstw strzegą-

\footnotetext{
${ }^{53}$ Alföldi 1973: 32-33; Zanker 1973: 48-49.

${ }^{54}$ Bert Lott 2004: 137-169.

${ }^{55}$ Kultem Lares Publici zajmujemy się w innym studium.
} 
cych $^{56}$ mieszkańców Rzymu przed zagrożeniami zewnętrznymi. Świadczyć ma ona o tym, że Lary są, obok zapewniającego pokój Augusta, reprezentowanego przez swojego Geniusza, boskimi obrońcami Miasta.

Pozostaje nadal wiele nierozstrzygniętych kwestii związanych z kultem Larów, nasze postrzeganie tego zagadnienia koncentruje się głównie na wierszach poezji Owidiusza.

\section{BIBLIOGRAFIA}

Teksty źródłowe, przekłady, komentarze

Braccini 2004: T. Braccini, Carmen choliambicum quod apud Ps.-Callisthenis Historiam Alexandri reperitur, Berlin 2004.

Corell 1999: J. Corell, Inscripcions romanes d'Ilici, Lucentum, Allon, Dianium, i els seus respectius territoris, Valencia 1999.

Cornell 2013: The Fragments of the Roman Historians, vol. I. Introduction, ed. T.J. Cornell, Oxford 2013.

Lindsay 1913: Paulus Diaconus, Sexti Pompei Festi, De verborum significatu quae supersunt cum Pauli epitome, ed. W.M. Lindsay, Leipzig 1913.

Frazer 1989: Publi Ovidii Nasonis Fastorum libri sex. The Fasti of Ovid, ed. J.G. Frazer, vol. IV, London 1989.

Hohl 1997: Scriptores Historiae Augustae, vol. II, ed. H. Hohl, Studgardiae et Lipsiae 1997.

Kuebler 1888: Iuli Valeri Alexandri Polemi Res gestae Alexandri Macedonis translatae ex Aesopo Graeco, recensuit B. Kuebler, Lipsiae 1888.

Owidiusz 2008: Owidiusz, Fasti. Kalendarz poetycki, przekł. i oprac. E. Wesołowska, Wrocław 2008.

Plaut 1951, Kupiec, przeł. i oprac. G. Przychocki, przyg. W. Strzelecki, Wrocław 1951.

Plaut 2003, Plaut, Komedie, t. II, Osty, Misa petna złota, przekł. i oprac. E. Skwara, Warszawa 2003.

Rodges 2004: R.H. Rodges, Frontinus. De aquaeductu Urbis Romae, Cambridge 2004.

Rosellini 2004: Res gestae Alexandri Macedonis translatae ex Aesopo Graeco, ed. M. Rosellini, Monachii et Lipsiae 2004.

Suetonius 1979: Suetonius with an English Translation by J.C. Rolfe, vol. I, Cambridge, Massachusetts, Harvard 1979.

\section{Opracowania}

Alföldi 1973: A. Alföldi, Die zwei Lorbeerbäume des Augustus, Bonn 1973.

Alton, Courtney, Wormell 1973: E.H. Alton, E. Courtney, D.E.W. Wormell, Problems in Ovid's Fasti, „Classical Quarterly” 23 (1973), 144-151.

Beard, North, Price 1998: M. Beard, J. North, S. Price, Religions of Rome, vol. I: A History, Cambridge 1998.

Bert Lott 2004: J. Bert Lott, The Neighborhoods of Augustan Rome, Cambridge 2004.

Bodel 2008: J. Bodel, Cicero's Minerva, Penates, and the Mother of the Lares: An Outline of

${ }^{56}$ Coarelli (2003: 52-53) uważa, że mit o Romulusie i Remusie łączy się z mitem o Lares Praestites jako założycielach i obrońcach miasta, związanych z opowieścią o Akce Larencji. Lary są w jego opinii bóstwami o charakterze chtonicznym. 
Roman Domestic Religion, w: Household and Family Religion in Antiquity, eds. J. Bodel, S. Olyan, Oxford 2008.

Bonniec Le 1960: H. Le Bonniec, Notes critiques sur les Fastes d'Ovide, „Revue de philologie, de littèrature et d' histoire anciennes" 34 (1960), 194-215.

Bömer 1981: F. Bömer, Untersuchungen über die Religion der Sklaven in Griechenland und Rom, część 1, Wiesbaden 1981

Brennan 1994: T.C. Brennan, M'. Curius Dentatus and the Praetor's Right to Triumph, „Historia: Zeitschrift für Alte Geschichte" 43 (1994), z. 4, 423-439.

Coarelli 2003: F. Coarelli, Myth and Culture in Republican Rome. Studies in Honour of T.P. Wiseman, eds. D. Braund, Ch. Gill, Exeter 2003.

Crawford 1974: M.H. Crawford, Roman Republican Coinage, Cambridge 1974.

Cary, Scullard 1992: M. Cary, H.H. Scullard, Dzieje Rzymu. Od czasów najdawniejszych do Konstantyna, t. I, przeł. J. Schwakopf, Warszawa 1992.

Dębiński, Misztal-Konecka, Wójcik 2010: A. Dębiński, J. Misztal-Konecka, M. Wójcik, Prawo rzymskie publiczne, Warszawa 2010, par. 23.

Dubourdieu 1989: A. Dubourdieu, Les origines et le développement du culte des Pénates à Rome. Ecole française de Rome, Rome 1989. [http://www.persee.fr/doc/efr_0000-0000_1989 ths 118 1].

Dury-Moyaers, Renard 1981: G. Dury-Moyaers, M. Renard, Aperçu critique de travaux relatifs au culte de Junon, Aufstieg und Niedergang der Römischen Welt, II, 17, 1, 1981, 142-202.

Fauth 1978: W. Fauth, Römische Religion im Spiegel der Fasti des Ovid, Aufstieg und Niedergang der Römischen Welt II 16, 1, 1978, 104-186.

Flaig 2013: E. Flaig, Zrytualizowana polityka. Znaki, gesty i władza w starożytnym Rzymie, oprac. L. Morozewicz, przeł. L. Mrozewicz, A. Pawlicka, Poznań 2013, 216.

Forcellini 1945: A. Forcellini, Lexicon Totius Latinitatis ab Aegidio Forcellini seminarii Patavini alumno lucubratum, deinde a Iosepho Furlanetto eiusdem seminarii alumno emendatum et auctum nunc vero curantibus Francisco Corradini et Iosepho Perin seminarii Patavini item alumnis emendatius et auctius melioremque in formam redactum, secunda impressio anastatice confecta quartae editionis aa. 1864-1926 Patavii typis mandatae cum appendicibus quibus aucta est prima anastatica impressio a. 1940 edita, vol. III Patavii 1945.

Farney 2007: G.D. Farney, Ethnic Identity and Aristocratic Competition in Republican Rome, Cambridge 2007.

Glare 1968: Oxford Latin Dictionary, ed. P.G.W. Glare, Oxford 1968.

Handy 2009: M. Handy, Die Severer und das Heer, Heilderberg 2009.

Jaczynowska 1987: M. Jaczynowska, Religie świata antycznego, Warszawa 1987.

Jenkyns 2013: R. Jenkyns, God, Space, and the City in the Roman Imagination, Oxford 2013.

Jurewicz 2001: Stownik grecko-polski, t. II, $\Lambda-\Omega$, oprac. O. Jurewicz, Warszawa 2001.

Kaczor 2012: I. Kaczor, Deus. Ritus. Cultus. Studium na temat charakteru religii starożytnych Rzymian, Łódź 2012, 221-230.

Korpanty 2001: Stownik łacińsko-polski, t. I i II, red. J. Korpanty, Warszawa 2001.

Krzyszowska 2002: A. Krzyszowska, Les cultes privés à Pompei, Wrocław 2002, 222-240.

Kunckel 1974: H. Kunckel, Der römische Genius. Mitteilungen des deutsche Archeologischen Instituts, Heidelberg 1974.

Meisels 1999: W. Meisels, Podręczny słownik włosko-polski, t. II, Warszawa 1999.

Orr 1978: D.G. Orr, Roman Domestic Religion: The Evidence of the Household Shrines, ANRW II, Principat, 16.2, Berlin-New York, 1978, 1557-1591.

Niebling 1956: G. Niebling, Laribus Augustis magistri primi. Der Beginn des Compitalkultes der Lares und des Genius Augusti, „Historia: Zeitschrift für Alte Geschichte” 5 (1956), 303-331.

Palmer 1990: R.E.A. Palmer, Studies of the Northern Campus Martius in Ancient Rome, „Transactions of the American Philosophical Society”, 80 (1990), part 2, 
Palombi 1997: D. Palombi, Aedes Deum Penatium in Velia. Note di topografia e storia, „Mitteilungen des Deutschen Archäologischen Instituts Römische Abteilung” 104 (1997), 435-463.

Pauly-Wissowa-Kroll 1910: A. Pauly, G. Wissowa, W. Kroll, Paulys Realencyclopädie der classischen Altertumswissenschaft neue Bearbeitung, vol. VII, 1910.

Plezia 1959-1979: Słownik łacińsko-polski, t. I-V, red. M. Plezia, Warszawa 1959-1979.

Redentor 2017: A. Redentor, A cultura epigráfica no Conventus Bracaraugustanus (pars occidentalis). Percursos pela sociedade brácara da época romana, „Imprensa da Universidade de Coimbra", Coimbra 2017.

Sajkowski 2000: R. Sajkowski, Genius Augusti. Charakter kultu geniusza w okresie Republiki, w: Z antycznego świata: religio - cultus - homines, red. W. Appel, P. Wojciechowski, Toruń 2000, 52-72.

Samter 1901: E. Samter, Familienfeste der Griechen und Römer, Berlin 1901.

Scheid 1990: J. Scheid, Romulus et ses frères. Le collège des frères arvales, modèle du culte public dans la Rome des empereurs, Rome 1990.

Stankiewicz 1987: L. Stankiewicz, Tytyniusz - przedstawiciel komedii rzymskiej zwanej fabula togata, Wrocław 1987.

Stankiewicz1999: L. Stankiewicz, Komedia Lucjusza Afraniusza i jej zwiąki z innymi odmianami komedii, Wrocław 1999.

Stöckinger 2013: M. Stöckinger, Inalienable Possessions. The di penates in the Aeneid and in Augustan Culture, w: La costruzione del mito augusteo, eds. M. Labate, G. Rosati, „Bibliothek der klassischen Altertumswissenschaften", vol. CILI, Heidelberg 2013.

Sumi 2009: G.S. Sumi, Monuments and Memory: The Aedes Castoris in the Formation of Augustan Ideology, „Classical Quarterly” 59 (2009), część 1, 107-186.

Tabeling 1932: E. Tabeling, Mater Larum. Zum Wesen der Larenreligion, „Frankfurter Studien zur Religion und Kultur der Antike", Frankfurt am Main 1932.

ThLL 1992: Thesaurus Linguae Latinae vol. X, 2 fasc. VI: praepotens-praesuscipio, Teubner 1992.

Thomson de Grummond 1996: Encyclopedia of the History of Classical Archaeology, ed. N. Thomson de Grummond, London and New York, 1996.

Urban 1999: R. Urban, Gallia rebellis. Erhebungen in Gallien im Spiegel antiker Zeugnisse, Stuttgart 1999.

Vaan 2008: M. de Vaan, Etymological Dictionary of Latin and the other Italic Languages, Leiden-Boston 2008.

Várhelyi 2010: Z. Várhelyi, The Religion of Senators in the Roman Empire. Power and beyond, Cambridge 2010.

Walde-Hofmann 1938: A. Walde, J.B. Hofmann, Lateinisches etymologisches Wörterbuch, vol II, Heidelberg 1938.

Wissowa 1912: G. Wissowa, Religion un Kultus der Römer, München 1912, 169-176.

Witczak 2005: K.T. Witczak, Język i religia Luzytanów. Studium historyczno-porównawcze, Łódź 2005.

Zanker 1973: P. Zanker, Studien zu den Augustus-Porträts. I. Der Actium-Typus, Abhandlungen der Akademie der Wissenschaften in Göttingen, Philologisch-Historische Klasse 3 nr. 85, Göttingen 1973.

Ziółkowski 1992: A. Ziółkowski, The Temples of Mid-Republican Rome, Roma 1992. 


\section{WHOM WERE THE LARES PRAESTITES GUARDING?}

\section{S u m m a ry}

The paper examines the verses of the $5^{\text {th }}$ book of Ovid's Fasti $(5,129-139)$, which offer an account of the Roman gods called Lares Praestites. The poet presents their activity as the guardians of Rome referring to the archaic worship of Lares and the feast day dedicated to them.

The cult of the gods, attested only by the poet of Sulmo, is described by him in detail also by the use of words referring to their epithet Praestites, as praestant, stant pro (nobis), praesunt, praesentes. The analysis of the works in which the ancient writers use the term praestes, also epigrafhic ones, shows that this noun denotes "guardian" and is most often applied to gods, e.g. Iuppiter. However, in none of the surviving writings, except for the one composed by the author of Fasti, the noun is proposed as an epithet of Lares. 